\title{
Concepts of Board Performance: Review of Performance Metrics in Boards Research
}

\author{
Miika Kuoppamäki ${ }^{1}$ \\ ${ }^{1}$ Witten/Herdecke University, Witten, Germany \\ Correspondence: Miika Kuoppamäki, Witten/Herdecke University, Witten, North Rhine-Westphalia, Germany.
}

Received: June 12, 2018

Accepted: July 2, 2018

Online Published: July 22, 2018

doi:10.5430/jms.v9n3p41

URL: https://doi.org/10.5430/jms.v9n3p41

\begin{abstract}
This paper discusses concepts of board performance. Long traditions exist for using corporate financial metrics as indicators of board performance. I argue that a financial perspective alone is insufficient and sometimes misleading, and thus suggest addition of alternative measurement concepts.

Arguments are based on analysis of extant research on boards and board directors. The concepts proposed in this paper are building on strategic review of board research articles in main international academic journals. I conclude from the research that board performance should be measured based on how boards are contributing to value creation. It was illustrated though the review that value creation takes place in intermediate steps and that board performance should be measure accordingly.
\end{abstract}

Keywords: board performance, performance concepts, performance measurement

\section{Introduction}

Purpose of this paper is to understand types of contributions board directors provide towards firm performance and how those contributions can be measured. If effect of board inputs varies between an overall stronger or weaker impact, this can be viewed as varying levels of board performance. Assigning indicators to measure that influence will allow gauging levels of board performance. Frequent practice in measurement of board input is building on an input/ output model, where input is board member qualification and output is firm performance measured through corporate financial data. Corporate financial data is an important, yet insufficient concept as a singular metric. Purpose of this paper is therefore to understand perspectives of board performance measurement beyond corporate financial data and to outline concepts for alternative metrics.

Financial indicators are at the core of an agency motivated control perspective (Fama \& Jensen, 1983), where key purpose of measurement is to fulfill board fiduciary duties. They capture certain aspects of firm functioning rather well, but are not suitable to measure all types of performance. Therefore relying on financial metrics as a singular board performance measuring convention is likely to yield incomplete results. In contrast a stewardship motivated trust perspective (Donaldson, 1990) relies on a broader set of metrics. This has been exemplified in balanced scorecard approaches derived from stewardship theory principles (Kaplan \& Norton, 1996). Balanced scorecards have also been applied to management of board performance (Northcott \& Smith, 2011). Northcott \& Smith's (2011) survey indicate behavioral measures of board performance are generally perceived more useful by board members than operational and financial measures. In comparison to board internal views of board performance Forbes \& Milliken (1999) argue value creation takes place in intermediate steps. Therefore board performance needs to be measured accordingly. A board internal and external view is required (Huse, 2005). Extant board performance literature is reviewed to uncover a set of board performance concepts capturing different aspects of performance to meet all requirements described above.

Challenges arising from a singular measuring convention become evident in an invitation by Private Company Director Magazine, issued in February 2017. The call invited nominations for high performing private company boards. Performance criteria 1-6 for participating boards are summarized in a table below. 
Table 1. Performance criteria for participating boards

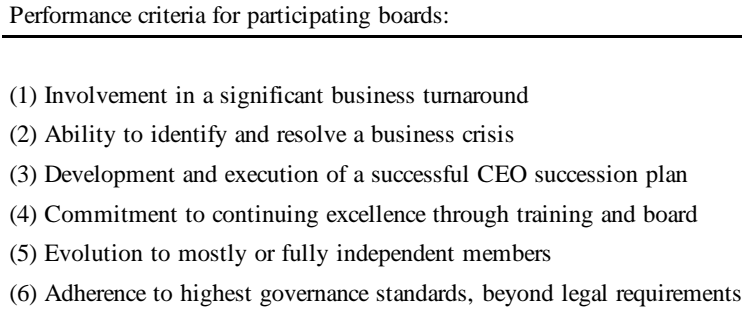

Analyzing the list above, qualification criteria included strategic $(1,2,6)$, organizational $(3,5)$, and process related (4) matters. And as none of the indicators were based on financial data, the question arises, how these qualification criteria could be measured based on a traditional input/ output model. The answer is simple, they cannot be measured through financial indicators only. In this paper I would like to address this gap by proposing additional concepts for board performance measurement.

Use of financial metrics in research of board performance is motivated by a control perspective and ease of use as this data is readily available. Input-output models of board performance rely on input metrics such as experience, academic qualification and other responsibilities held. Output metrics are based on corporate financial performance measured over time, such as sales revenue, return on investment and firm growth. Two concerns arise from reflection on financial metrics as board performance indicators. Financial data can be misleading and there is a risk of bias in a singular performance concept approach.

Also, indicators used in financial accounting like debt, cash conversion rate or dividend affordability can be misleading. Net debt figures do not always convey the full level of indebtedness, as is the case when not all creditors are included into debt to earnings calculations due credit classification variations. Cash conversion rate can vary for the same reason, sometimes allowing for short term payment facilities to be presented as cash flow from operations instead of financing. And ability to pay dividends can be indicated as payout to earnings ratio without full disclosure of the level of indebtedness.

While it can be argued that good financial results are informed by the board's contribution to firm performance, causality is difficult demonstrate. Obvious benefit of this approach is availability of accessible data on both board directors and corporate financial performance. From an agency theory perspective key task of the board as principal is to control the company's CEO as the agent (Fama \& Jensen, 1983). Challenge arises from the fact, that distance between the board as a subject and corporate financial data as the point of measurement will have significant impact on accuracy of a metric. The further detached the measurement points are in a correlation relationship, the more difficult it is to attribute a result to the subject of study.

Without measurement it is difficult to say, whether the board creates value for the company or if management would do equally well without any board supervision. If measurement concepts do not establish a connection between the board and the broader firm organization it will be difficult to assess, whether board activities do have a positive or negative impact on the company, or maybe no effect at all.

A Financial Times article attributed recent difficulties at VW and Deutsche Bank to board failures and shortcomings of the German two-tier board system (Financial Times, 2018a). The newspaper article suggests reason for insufficiency of the board being too strong ownership representation in the supervisory board. By the same token a planned shift towards more financial director profiles was highlighted as a plausible remedy. Reflecting on the emissions rigging scandal as the main factor having led to ousting of two Chief Executives in short succession, reasonable doubt can be expressed about whether more financial understanding would have prevented the difficulties. It could be argued instead, that embedding core company functions deeper into the board might have been more useful to ensure proper understanding of the risks involved. Directors with an R\&D, product development or legal background might have been more forthcoming about the negatives of emission rigging software.

Pragmatic reason for an input/ output model measuring convention is academic researchers' lack of access to board proceedings. From scholarly research perspective the board is often considered a black box whose inner dealings rarely become visible to the external observer (Gabrielsson \& Huse, 2004, p. 11). Transparency would be a key requirement for development of performance metrics with closer proximity to the board. Data available through a 
disclosure mandate for public companies explains both the focus in corporate governance on listed companies and financial indicators. Further limitation of an input/ output approach is failure of financial indicators to allow broader insights into firm performance. A thorough understanding of board and firm performance calls for definition of a broader range of measurement concepts.

This paper undertakes an effort to outline additional measurement concepts through expansion of board performance metrics into strategic, organizational and process perspectives. This shall be achieved through a literature review building on an overview provided by Gabrielsson and Huse (2004). Evidence for prior use of the concepts in academic papers is offered through analysis of extant research. A further analysis of the concepts will establish the four perspectives as distinct concepts for board performance measurement. Summarizing discussion and conclusions will highlight implications for management sciences research and practitioners.

\section{Theoretical Framework}

Starting point for this enquiry are two questions which have been asked by scholars before: What is it that boards really do (Mace, 1971) and what constitutes great boards (Sonnenfeldt, 2002; Nadler, 2004). When we understand task and purpose, we can define measurement concepts. As a metric is always specific to the task and a desired outcome, this paper argues for the necessity of opening the black box of board activity. This is to allow for meaningful measurement of board performance (Forbes and Milliken, 1999). The need for measurement of managerial activities has been laid out by Mace (1971), and the limitations of financial metrics as board performance indicators argued by Zahra and Pierce (1989). Yet the difficulty of measurement remains (Pettigrew, 1992). And before attempting any measurement, it needs to be established how performance should be measured (Hillman and Dalziel, 2003; Aguilera 2008).

Motivation for use of different performance concepts can be derived from theoretical perspectives applied in board performance considerations. In an agency perspective (Jensen \& Meckling, 1976; Fama \& Jensen, 1983) financial metrics can be deemed sufficient. The board's fiduciary responsibility and success controlling opportunism are expressed in the extent to which firm commercial success is maximized. A more collaborative stewardship perspective (Donaldson, 1990) suggests a broader set of performance metrics. A balanced scorecard model as proposed by Kaplan and Norton (1993) has been derived from stewardship perspective. While theoretical soundness of a balanced scorecard view has been questioned by Nørreklit (2003), it has also been applied in the context of board performance (Epstein \& Roy, 2004; Northcott \& Smith, 2011). Board members surveyed by Northcott \& Smith (2011) reported preference for behavioral measures of board performance over operational and financial measures. In a team production (Blair \& Stout, 1999) and extended team production (Huse \& Gabrielsson, 2012) approach leveraging a broader set of concepts is essential. Purpose of this paper is to identify additional concepts in extant board and board director research.

Purpose for selection of the sample as a starting point is to demonstrate a tradition for prior use of multiple board performance perspectives in extant research. The sample assembled by Gabrielsson and Huse (2004) is selected for several reasons. It serves as a suitable sample focusing on academic rigor of the chosen articles. It further includes papers applying a range of different research angles. In this paper I am demonstrating that the four concepts have been used broadly in more than one type of research approach. Building on extant research and established scholarly views supports an argument for broadening the scope of board performance measurement. The sample is leveraged to point out a discrepancy between extant research and preferred board performance measurement conventions. While all four selected performance concepts are discussed in extant boards and board director research, board performance considerations mostly focus on financial metrics. Practitioner views can also differ from a singular financial focus, as is demonstrated in the Private Company Director Magazine call for submissions.

A body of research has been conducted on board performance. Initially an agency motivated board control perspective advocates financial performance as the key board performance metric to satisfy the board's fiduciary responsibility (Jensen \& Meckling, 1976). But use of financial metrics finds broad support also from other perspectives (Bushman \& Smith, 2001; Daily et al, 2003; Nørreklit, 2003; Voelpel et al, 2006; Zahra \& Pearce, 1989). Focus on organizational performance rises from behavioral theory of the firm (Cyert \& March, 1963) and Myles Mace's (1972) effort to define board responsibilities. In later research organizational performance has been discussed in particular from a behavioral perspective (Roberts et al, 2005; Huse, 2008; Minichilli et al, 2012). Significance of board strategy performance has been laid out by Forbes and Milliken (1999). It has further been discussed by Hendry and colleagues (2010), as well as Machold, Huse, Minichilli and Nordqvist (2011). Process performance builds on perspectives developed by Andrew Pettigrew (1992) and also Finkelstein and Mooney (2003). Impact of processes on board performance are discussed in extant research by Pye and Pettigrew (2005) and Zahra 
(2007). Use of the selected performance concepts in extant research provides the rationale for focusing on these four concepts in board performance considerations.

A perspective based on a stewardship theory view will integrate also other company resources into the measurements and extend board responsibilities deeper into the firm. A team production theory working assumption will support use of other firm resources as proxies for board performance measurement. As board value creation takes place in intermediate steps, metrics need to reflect the nature of board performance. It can be argued that corporate financial performance metrics are almost exclusively the result of corporate management and the broader organization's accomplishments. Depending on governance model and company legal residence the board does not partake in operative business. When dividing board tasks into control, service and advisory tasks it becomes evident, that a financial metrics only output perspective does not cover strategic, organizational or process based angles of board performance. It is as such an insufficient measurement concept for board performance to stand alone.

This review is conducted with a strategic perspective, which focuses on discussion of alternative concepts for board performance measurement, in addition to corporate financial metrics. The research question this paper seeks to address is what meaningful angles of board performance measurement can be identified, other than corporate financial performance. And further, to what extent these have already been used in prior boards and corporate governance research. Motivation for the research stems from lack of transparency into board activities from an academic perspective and the black box challenge (Gabrielsson \& Huse, 2004). Purpose of the paper is to address the resulting difficulty of board performance measurement and to identify additional concepts.

The inherent challenge of any kind of measurement is to ensure that a chosen metric measures what the researcher intends to measure. E.g. annual revenue from sales activities or return on capital invested do not allow for immediate conclusions about board performance in terms of efficiency of board internal collaboration. To understand good performance, it is first necessary to determine definitions for "good" and for "performance". The assumption that this principal level challenge equally applies to measurement of board performance necessitates discussion of criteria for performance and means for measurement.

Prior to measuring, it is important to understand the definitions for good and performance, with the first part clarifying what constitutes a high performing board. Research shows that contrary to expectations boards of failed corporations typically did not consist of incompetent people, did not fail to implement control systems and did not lack common governance mechanisms. Empirical evidence shows there is little difference in age, composition, board size, level of board equity investment or competencies of board members between successful and failed companies (Dalton et al, 1999). While an increase of external board members has been partly mandated, even the mix of internal and external board members cannot be attributed as a cause. Consequently, Sonnenfeldt (2002) and others are asking for new thinking about how boards should operate and how they should be evaluated.

Second part of the question goes back to Mace (1972) and board task definition. An attempt to measure requires ex-ante clarification of directors' tasks and the perspectives required to meet board member responsibilities. Therefore, transparency of board tasks is of the essence. As soon as a task is defined, performance can be measured. In an approach focusing on structures Zahra and Pearce (1989) analyze boards from four theoretical perspectives, a legalistic, resource dependence, class hegemony and agency theory perspective. Financial performance measurement was attempted through an integrative model, consisting of four board attributes composition, characteristics, structure and process. To develop a framework Zahra and Pierce differentiated between service, control and strategy tasks and introduced the concepts of social and systemic performance (on systemic performance see Daft, 1989; Chaganti et al, 1985).

Differing from Zahra and Pearce (1989), Andrew Pettigrew (1992) proposes a processual perspective on board research and focuses his research on understanding of board processes. Key critique of earlier theories is detachment of the research from actual actors, processes and issues which board directors are facing. To mitigate this fact Pettigrew argued for a processual perspective to complement prior research traditions and to lessen the scholarly black box problem. He claims that the black box contains the essence of enquiry for the process scholar to understand development, conduct, impact and performance of the board itself.

Complementing Pettigrew, Gabrielsson and Huse (2004) argued existing research conventions based on availability of data do not deliver on the target of improving understanding of boards. Measurement of corporate financial performance allows understanding of value creation to shareholders, but is not suitable as a board performance indicator. The difficulty of attributing any direct effect to the board (Daily et al, 2003) and ambiguity of any effects were considered limitations (Johnson et al, 2006). Further, a short-term focus (Aguilera and Jackson, 2003) and lack of behavioral perspectives (Forbes and Milliken, 1999; Mace, 1971) has been pointed out. 
While use of corporate financial data for board performance measurement allows for development clear metrics, a too strong focus on one type of metric bares the risk of groupthink (Janis, 2015). In corporate governance context this particular risk has been discussed e.g. in relation to the recent credit crisis (McNulty et al, 2013) and the Enron scandal (Howard, 2010).

In Gabrielsson and Huse (2004) input-output studies (see e.g. Kosnik, 1987; Davis, 1991; Ocasio, 1994 and 1999; Westphal and Zajac, 1994), contingency studies (see e.g. Pettigrew, 1992; Samra-Fredericks, 2000; Pye and Pettigrew, 2005), behavioral studies (see e.g. Pearce and Zahra, 1991; Westphal and Zajac, 1998; Ng and Cock, 2002) and evolutionary studies (see e.g. Christensen and Westenholz, 1999; Pye, 2002), each show their limitations in practical application and pave the way for a more evolutionary approach.

With a different perspective Johnson, Daily and Ellstrand (1996) propose director independence from control, service and resource dependence perspectives and a focus on board composition instead. This view was argued based on inter-relationship between board, firm management and stockholders. No consensus was however found on commonly accepted board performance measures for financial or other performance.

In summary, financial metrics are deemed insufficient, a structural perspective proving too rigid and a processual approach or different research models do not eliminate the black box. Similarly, nomination of independent directors does not address board performance to satisfaction. Hence, the contribution of this paper is to establish additional measurement concepts for board performance research. It shall result in a more comprehensive understanding of board performance perspectives, which is important, as we can only improve what we can measure. Advocating change without metrics is guesswork.

\section{Research Method}

To meet the objective laid out in the research question this analysis is conducted as a strategic review. The strategy applied is selection of four performance perspectives with the target to find support for their suitability as concepts for board performance measurement. While other might exist, the strategic review angle allows to focus the analysis on four distinct concepts: financial, organizational, strategy and process performance. The approach was chosen, to demonstrate use of the performance perspectives in extant research and deduct concepts for future board performance research.

Approach: A literature research was conducted as a four-stage analysis consisting of concept construction, sampling, observation and analysis. While other samples could have been chosen, reason for selection of the Gabrielsson and Huse (2004) sample was that it provided a suitable basis for a conceptual analysis. The sample is constructed from review of 200 journals from boards of directors and corporate governance research. Four US American and two European journals are selected based on being considered scientific and for containing the most publications on boards.

This paper builds on use of the concept of financial performance as a means to measure board performance. Financial performance comprises measurements based on analysis of financial indicators from operative business, such as sales revenues, profit margin or return on investment (Zahra and Pearce, 1989). Following a similar approach three additional concepts are examined, measuring strategic, organizational and process performance. Together these four concepts are the topic of research in this paper and the building blocks used to argue the position that there is a need for additional concepts for board performance measurement.

Building on Gabrielsson and Huse (2004), the approach is structured based on positioning board performance within the boundaries of financial performance as described by Zahra and Pearce (1989) and further discussed by Nørreklit (2003) and Voelpel and colleagues (2006). In addition, a strategic perspective is reviewed, as chosen by Pettigrew (1992), Schmidt and Brauer (2006) and Hendry, Kiel and Nicholson (2010). An organizational view building on Cyert and March (1963) and further discussed by Davis (1991), as well as Aguilera et al (2008) are deemed essential. Ultimately a process view as outlined by Pye and Pettigrew (2005), Samra-Fredericks (2000), and also discussed by Finkelstein and Mooney (2003) forms the fourth perspective of analysis. These concepts are identified as suitable means for board performance evaluation of financial, strategy, organization and process effectiveness. These perspectives are therefore chosen as suitable concepts for broader observation and analysis.

Sample size: 217 articles from six (6) general management journals are obtained from the Gabrielsson and Huse (2004) overview. While the data sample is not comprehensive, it is structured to offer a longitudinal sample of 6 high quality general management journals, covering an international perspective with publications from the USA (4), the UK (1) and Italy (1) included. Using the paper as a starting point allows an important retrospective view of board research. Purpose is to find support for use of the concepts in extant research. 
Data collection: Articles from Gabrielsson and Huse (2004) are used as a primary sample to observe the extent to which the four concepts can be aligned within a research framework. Use of the sample allows to establish angles of board performance measurement used in prior research and to gauge extent of their use. Representation of any of the four performance concepts within the data is analyzed for references in title, abstract or broader context of the paper.

Method: To expand on the singular focus on financial indicators the perspective is expanded to include strategic, organizational and processual perspectives. Use of one singular concept is deemed insufficient for board performance measurement. The sample is studied using a framework of four research methods and four performance concepts. Purpose is to find evidence for prior use of the performance concepts and their suitability for different research settings. Combining four concepts into an evolutionary perspective of board performance and serving as a basis for further research.

For differentiation between the board performances concepts following definitions are formulated:

Table 2. Definitions of board performance concepts

\begin{tabular}{|c|c|}
\hline Performance concept & Concept definition \\
\hline Financial performance & $\begin{array}{l}\text { Financial performance is defined as performance adding financial value to } \\
\text { shareholders. Examples of such metrics are sales revenues, gross margin, } \\
\text { return on investment, return on net assets, return on equity, as well as } \\
\text { improvement in the firm's stock market performance (see e.g. Zahra and } \\
\text { Pearce, 1989; Nørreklit, 2003; Voelpel et al, 2006.) }\end{array}$ \\
\hline Organizational performance & $\begin{array}{l}\text { Organizational performance is defined as performance derived from } \\
\text { organizational activities, adjustments to people policies, changes in } \\
\text { organizational models, as well as training and education to grow knowledge } \\
\text { and cognitive skills. Organizational performance typically also impacts } \\
\text { financial performance (see Cyert and March, 1963; Nadler, 2004; Aguilera et } \\
\text { al, 2008.) }\end{array}$ \\
\hline Strategic performance & $\begin{array}{l}\text { Strategic performance is attributed to performance resulting from } \\
\text { adjustments to corporate resources and structures, operational focus areas or } \\
\text { business models, based on strategic decision-making. Strategic performance } \\
\text { typically impacts financial or other forms of performance inside the firm } \\
\text { (see Pettigrew, 2002; Schmidt and Brauer, 2006.) }\end{array}$ \\
\hline Proces performance & $\begin{array}{l}\text { Process performance is attributed to performance resulting from adjustments } \\
\text { to the firm's ways of operating, such as sets of tasks, processes and } \\
\text { operating principles. Process performance typically leads to other forms of } \\
\text { performance inside the firm (see Finkelstein and Mooney, 2003; Pettigrew, } \\
\text { 1997; Pye and Pettigrew, 2005; Saundra-Fredericks, 2000.) }\end{array}$ \\
\hline
\end{tabular}

A strategic literature research is conducted and the sample is reviewed against four performance types. The concepts are used to introduce additional performance angles and to offer a broader perspective of board performance beyond the scope of financial metrics. A research framework connects research models identified by Gabrielsson and Huse (2004) with the four performance measurement types. In the sample Gabrielsson and Huse (2004, p. 19) distinguish between four different research models used in the scientific articles. Using the sample as a basis allows to demonstrate use of the four performance concepts in different research settings. A framework is used to argue use of the selected research sample in the paper.

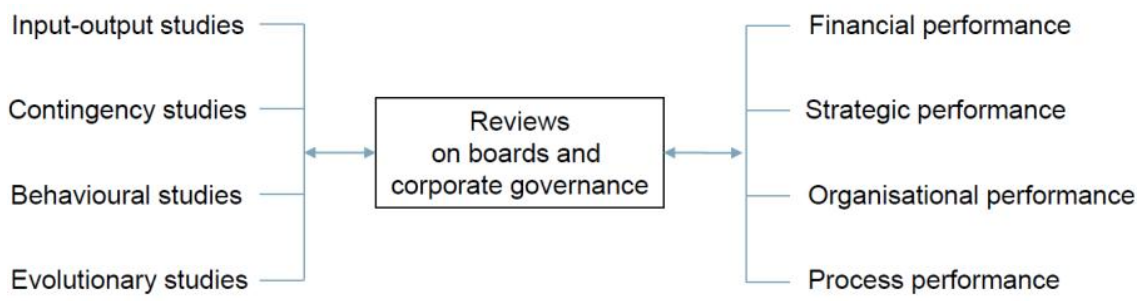

Research models $\quad$ Measurement concepts

Figure 1. Framework of research models and measurement concepts in the sample 
The framework used in this paper connects four distinct research models with four measurement concepts. As each research model investigates different properties, showing use of the four concepts in different research settings is essential to demonstrate their broader applicability. Understanding distinctions between the four research models demonstrates suitability of the concepts for different research settings. As described by Gabrielsson and Huse (2004), input/ output studies focus on widely researched attributes and structural board characteristics, such as size, insider/ outsider ratio or director shareholdings. These studies typically leverage readily available secondary data. Contingency studies examine contextual factors where stakeholder perspectives are analyzed to assess relative power of the board relative to in context of the firm. Behavioral studies assess board internal and external relationships and interactions of actors and processes in decision-making. Evolutionary studies investigate context and behavior.

\section{Analysis and Results}

A strategic literature review of academic articles discussing board performance in scientific journals returns an understanding of use of the concepts in extant research. The research intent to assess use of the four performance measurement concepts in an international sample is therefore met. Based on the analysis all four concepts are represented in the selection of 127 academic articles. Prior use of the chosen performance perspectives is shown and four concepts are established to measure financial, strategic, organizational and process board performance. This lays the foundation for a framework for board performance research based on four distinct board performance concepts.

While not all papers in the sample feature a performance perspective, most of them do. Out of 127 referenced articles, topics referring to organizational and financial performance are the most prevalent. With 49 (.385) referring to organizational, $30(.236)$ to financial, 15 (.118) to strategic and $6(.047)$ to process performance all concepts are represented. Several papers refer to more than concept. A total of 29 (.228) papers do not discuss performance related perspectives. A summary of the literature research shows application of performance concepts in the papers.

Table 3. Allocation of performance concepts in the papers

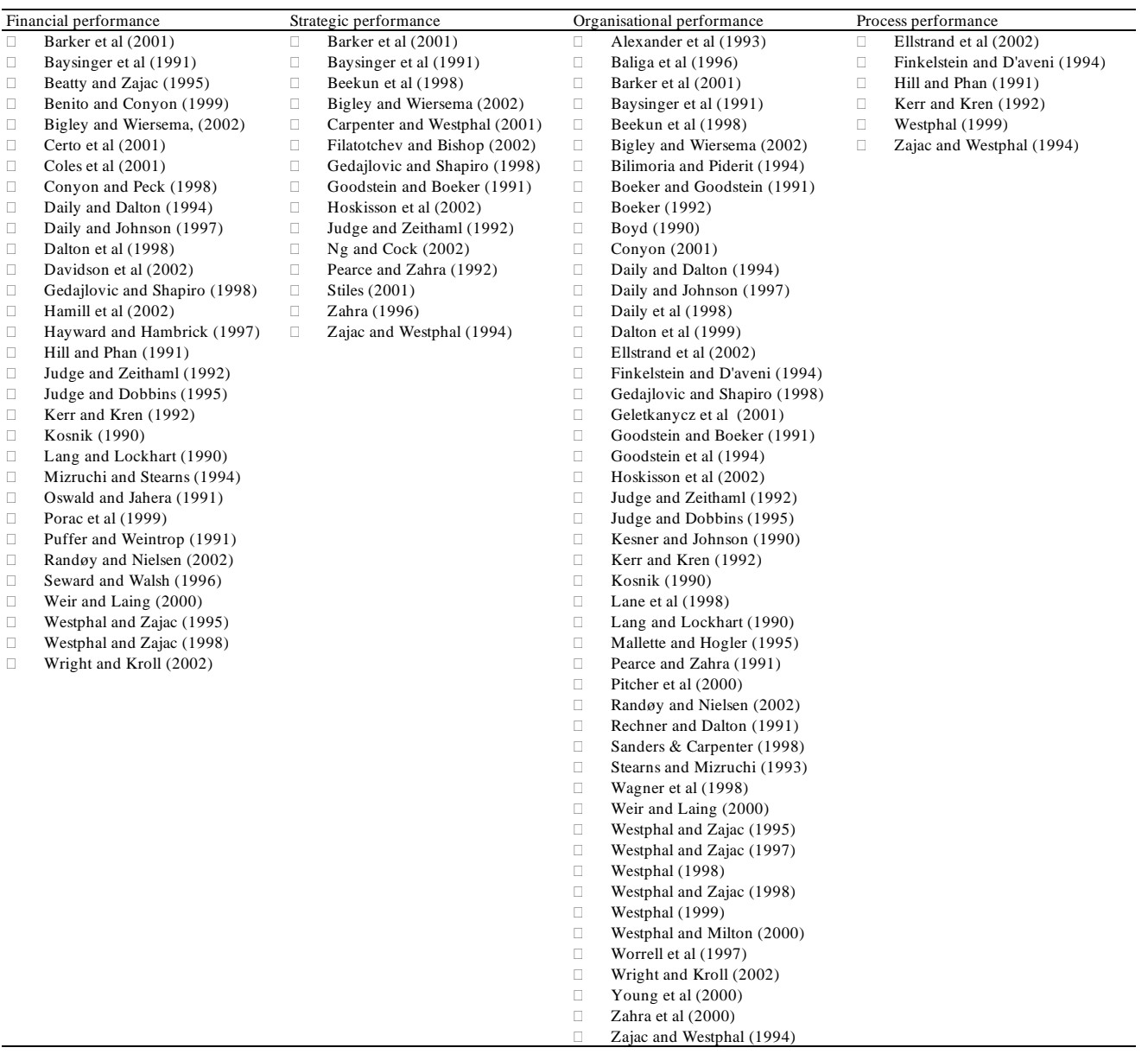


Not all concepts align equally with the sample and some concepts do find more application than others.

\section{Discussion}

In addition to the study of board performance based on research models, as introduced by Gabrielsson and Huse (2004), board performance research has evolved within several measurement concepts. Along with a financial perspective (Nørreklit, 2003; Voelpel et al, 2006; Cinquini \& Nørreklit, 2015), strategic (Pettigrew, 1992; Schmidt \& Brauer, 2006), organizational (Cyert \& March, 1963; Sonnenfeldt, 2002; Nadler, 2004; Aguilera et al, 2008; Zattoni and Cuomo, 2008) and process (Samra-Fredericks, 2000; Pye and Pettigrew, 2005) performance have been discussed in extant research.

More recently importance of an organizational performance perspective has been discussed in the context of effectiveness and organizational interdependencies by Aguilera, Filatotchev, Gospel and Jackson (2008). Similarly impact of board leadership on organizational performance has been examined by Gabrielsson, Huse and Minichilli (2007). Further, Minichilli, Zattoni, Nielsen and Huse (2012) position micro and macro perspectives of effort norms and cognitive conflict influence on board task performance. Para-González, Jiménez-Jiménez and Martínez-Lorente (2018) highlight effects between leadership and organizational performance.

Similarly importance of effectiveness to fulfill the board's strategic role ensuring consistency between firm strategy and resource allocation is discussed by Schmidt and Brauer (2006). Hendry, Kiel and Nicholson (2010) examine procedural and interactive strategizing, proposing a typology of board strategizing. Impact of leadership for strategizing is pointed out by Machold, Huse, Minichilli and Nordqvist (2011) highlighting larger influence of leadership behaviors on board strategy involvement compared to structural leadership characteristics. Analogously Garg and Eisenhardt (2017) discuss effects of board engagement in the strategy-making process, proposing a strategizing resource dependence process framework.

Building on Pettigrew's (1992) processual approach Pye \& Pettigrew (2005) examine impact of dynamic process factors on board effectiveness. Hambrick, Werder and Zajac (2008) analyze firm processes in the broader context of a micro/macro perspective. Subsequent research by Huse (2008) outlines concepts and methods for study of board processes. A more recent perspective by Zhu, Wang and Bart (2016) assesses impact of board processes on strategic decision-making and the board's ability to shape organizational performance.

In prior research a financial performance perspective emerges from the board's fiduciary control perspective and an input/ output view in boards and corporate governance research. It has been established in this paper, that singular focus on the concept of financial performance does not sufficiently measure the breadth of board performance (see Zahra and Pearce, 1989). In response to these findings we propose examination of organizational, strategy and process and task perspective in future research. This view is supported by the results, if this review, as scholars use financial metrics for performance measurement in only 30 articles (.236) out of 127 papers. All other reviews either rely on one of the three other performance concepts or alternatively performance was not a key topic in the paper.

This paper is addressing the paradox, that while multiple measurement concepts emerge from extant research, mostly only one concept is used in board performance frameworks. A broadening of perspectives has been proposed from a balanced scorecard standpoint by Epstein and Roy (2004), as well as Northcott and Smith (2011). But as the theoretical foundation of a balanced scorecard approach is subject to scrutiny itself (Nørreklit, 2003), lack of consensus prevails. The static nature of a balanced scorecard approach has been challenged by Nørreklit (2000) and the importance of a dynamic board perspective pointed out by Huse (2005). A more flexible board performance measuring convention, able to capture a broader set of performance concepts, is still required.

It can be argued, that due to the distance between the subject and the metric it is difficult to attribute any direct effects of financial performance to the board. While this is also true in case of the other performance concepts, a combination of several proxies and multiple perspectives is likely to yield a more comprehensive view board performance. Popularity of financial performance metrics is understandable as data is readily available and accessible (see Huse, 2008).

From practitioner perspective the risk of reliance on financial metrics as sole performance indicator has been recently portrayed in the demise of UK government outsourcer Carillion. While simultaneously advised by all big four auditors in different capacities, true representation of the firm's commercial feasibility only became evident when the company collapsed. In its bankruptcy filing Carillion reported GBP7 billion in debt and GBP27 million of cash at its disposal (Financial Times, 2018b; Financial Times, 2018c). Persisting lack of the board's ability to guide firm strategy and operations did not become evident from financial reporting. Failure of a single company does not suffice to argue groupthink (Janis, 2015) despite of the number of people and firms involved, but the same phenomenon has 
been observed elsewhere. Implications of industry level groupthink could be observed before the financial crisis of 2007-2008 when wide-spread negligence of subprime mortgage risk lead to severe instability in the financial markets (McNulty et al, 2013). Argument here is improved transparency gained through additional measurement concepts.

While financial metrics matter and corporate financial performance is scoring second highest among the metrics used in the survey, there is a need for complementary perspectives through additional concepts. Alternative and relevant perspectives are readily available. Additional concepts result from multiple angles in boards and corporate governance research. Board processes (Finkelstein \& Mooney, 2003; Pettigrew, 1992; Pye \& Pettigrew, 1995), board tasks (Forbes and Milliken, 1999; Huse, 2005) or application of a systemic angle (Huse, 1998) have been discussed in extant research. The concept of strategic performance emerges naturally from a board advisory task perspective, but also application of systemic angles requires a strategic view. In addition to a process focus (Pettigrew, 1992), systemic view (Huse, 1998), strategy execution efficiency (Schmidt and Brauer, 2006) and social and psychological factors inside boards (Westphal and Bednar, 2005) call for strategic performance measures. This is reflected in the data sample through 15 (.118) articles addressing strategic performance.

All these indicate a need for additional perspectives. This shows that the topic of board performance is more diverse than what can be measured through financial metrics. As such the concepts of strategic, organizational and process performance are introduced and their relevance discussed in the literature research. It can be said for any metric, however, that it is unlikely for any single concept alone being able to capture board performance comprehensively.

As boards and corporate governance research involves study of organizations and corporate structures it might not be surprising that organizational performance is at the core in most of the reviewed articles. An organizational view emerges from the study of board attributes, structures and a resource dependence perspective. With a share of 49 out of 127 articles (.385) this was also reflected in the sample. Some of the reviewed papers however applied both a financial and organizational performance perspective. Building on the study of structures (Cyert and March, 1963; Daily and Dalton, 1992) and culture (Sonnenfeldt, 2002), more recently organizational behaviors (Nadler, 2004; Zattoni and Cuomo, 2008) and policies (Aguilera et al, 2008) have been in the research focus.

The concept of organizational performance clearly offers the broadest perspective for research, which is visible in the sample. On the one hand, this is attributable to the fact, that organizational performance covers the whole of the organization. Yet, on the other hand it can be argued, that this is the area where most of the performance potential can be attained. It is not surprising that Sonnenfeldt (2002) concludes that the essence of high performance boards does not lie in rules and regulations, but rather in how people work together in the social system of a board. This is likely to be true for other parts of the organization as well. Huse (2018) has been pointing out the importance of actors and behaviors.

Expanding on the topic of organizational performance, problems arise from multiple angles: strategic confusion, misaligned or frequently changing plans, lack of transparency, varying agenda or political dissent to name a few. Hence, trust and challenge between board members, how board directors engage directly with the organization, mutual respect, as well as trust and candor in collaboration are key ingredients for high performance (see Sonnenfeldt, 2002; Nadler, 2004). Yet, remedies frequently focus on structural issues, instead of creation of a climate of trust and fostering a culture of open dissent. Use of flexible and changing board roles and ensuring individual accountability has been proposed to develop board performance (see Sonnenfeldt, 2002). Defining what constitutes a high performing board, i.e. establishing the right metrics for measurement, should be the first step in board performance measurement.

In the data sample we observe implications of the black box problem of board research (Huse, 1998). Due to lack of visibility into board activities, performance tends to be measured with available, yet unsuitable metrics. Even if the firm is doing well based on annual sales, EBIT or share price development that does not indicate actual board performance. Before Enron or WorldCom collapsed and the extent of Tyco's troubles became evident, publicly available financial indicators were in line with normal performance. It must be argued, that the boards of those companies should have become aware of the problems earlier. When the key question is how to establish the necessary visibility, broader performance measurement is a candidate.

A recent example for increasing importance organizational performance measurement is the re-emergence of Corporate Social Responsibility (CSR). Inclusion of CSR into EU regulations (EU Guideline 2014/95/EU) and corporate laws in European countries such as Germany signifies this development. In several EU countries issuing a Corporate Sustainability Report is mandated for corporations, similar to production of an annual report (Germany as of January 1,2017). Financial performance measures alone are therefore not sufficient anymore, even from a legal perspective. 
Finally, the concept of process performance naturally emerges from board processes and process-thinking related to corporate governance. While processes are the core of any corporate operationalization, the concept of process performance was only applied in 6 (.047) of the papers. As such process performance was the least utilized concept within the sample. This is interesting, as process evaluation offers most immediate opportunity for performance measurement from corporate practitioner perspective. Turn-side for academic scholars is that process evaluation requires a thorough insight into a company's operations and visibility can be a challenge. Other process perspectives have been focusing on context, process and time in board dynamics (Pye and Pettigrew, 2005) and inclusion of interpersonal routines (Samra-Fredericks, 2000) in board process research. The research sample and performance concepts are summarized in an overview.

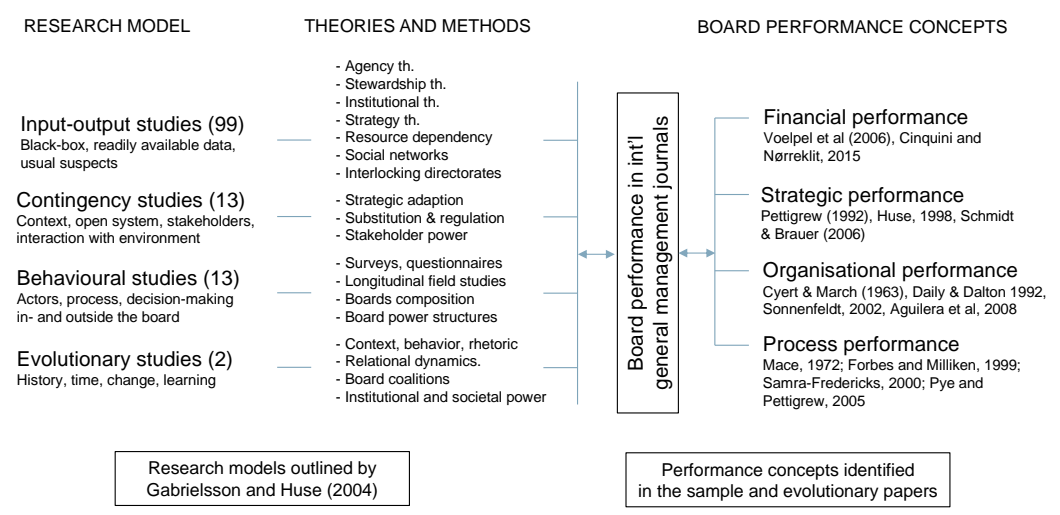

Figure 2. Research models, theories, methods and performance concepts in the sample

The summary shows consistent use of multiple performance concepts in extant literature. This supports an understanding that the four performance concepts are independent from research models, theories or concepts applied. As shown in the research, various concepts are considered suitable for board performance measurement in different research settings.

Similar to elevation of the importance of organizational performance in this paper, lack of understanding of behavioral processes and their influence on boards has been pointed out (Roberts et al, 2005). More recently a body of research on behavioral board perspectives has become available by Huse (2005), Van Ees, Gabrielsson and Huse (2009) and Gabrielsson and Huse (2012). Relaxation of agency theory perspectives has also been proposed (Huse et al, 2011) to allow for a broader perspective in board research. As the discussion of organizational and other performance concept examples show, definition of the right metrics is essential for value add of any future measurement. The question scholars need to consider in academic research is to what extent a test metric measures what the researcher intends to measure. For corporate boards, indicators need to take in consideration the breadth of perspectives board members are required to manage and the responsibilities directors bear. Consequently a broader set of metrics is necessary to allow for meaningful board performance measurement.

From scholarly perspective the question of adequate metrics and measurability of board performance is essential. In case increase of transparency is not achieved, board performance measurement in academic research will remain difficult. Contribution of this paper is demonstration of consistent use of multiple performance concepts in academic research and an argument for inclusion of additional performance perspectives in future boards and board director research. This paper is surfacing the paradox of multiple performance perspectives being used in extant research, but rarely implemented in a comprehensive board performance framework.

The consequence of lacking consideration of essential performance perspectives is simple. If certain types of board performance are not measured due to missing measuring conventions, these cannot be developed systematically. Resulting risk for academic board performance research is that its contribution will be marginalized. Therefore transparency of board performance and understanding of different performance concepts needs to be improved. Therefore I am calling for a new research agenda focusing on multiple perspectives of board performance research. 
This research shall focus on the four different performance concepts discussed in this paper. Consideration of financial, organizational, strategy and process performance perspectives is essential for future board performance measurement. Purpose is to determine how these concepts can be combined in a framework, and which metrics can be identified. Efficient metrics are likely to be specific to a specific firm situation and require to be adjusted when performance prerequisites change.

From practitioner perspective appreciation of a variety of board performance concepts is key to risk avoidance and long term success. As exemplified in the Carillion case, single concept focus and groupthink can have devastating consequences for company boards and the firm. Practitioner implication of this research is improved awareness of performance risks not surfaced through financial indicators.

\section{Conclusions}

This paper identifies financial, strategic, organizational and process concepts as suitable perspectives for research of board performance. Implementation challenge will be identification of effective metrics to support the identified concepts. How accessible indicators are, and how well metrics reflect board directors' work, will ultimately determine the value of a wider measurement perspective and use of the four concepts for evaluation of board performance.

We have seen board performance research evolving from the study of static elements, like attributes, structures and policies, towards more dynamic influencing factors, like cultures and behaviors. Correspondingly, measurement concepts based on a static view of organizations are likely to be superseded by more dynamic models in the future.

\section{References}

Aguilera, R. V., \& Jackson, G. (2003). The cross-national diversity of corporate governance: Dimensions and determinants. Academy of Management Review, 28(3), 447-465. https://doi.org/10.5465/amr.2003.10196772

Aguilera, R. V., Filatotchev, I., Gospel, H., \& Jackson, G. (2008). An organizational approach to comparative corporate governance: Costs, contingencies, and complementarities. Organization Science, 19(3), 475-492. https://doi.org/10.1287/orsc.1070.0322

Blair, M. M., \& Stout, L. A. (1999). A Team Production Theory of Corporate Law. 85 Va L Rev, 2, 247. https://doi.org/10.2307/1073662

Christensen, S., \& Westenholz, A. (1999). Boards of Directors as Strategists in an Enacted World-the Danish case. Journal of Management and Governance, 3(3), 261-286. https://doi.org/10.1023/A:1009977806089

Cyert, R. M., \& March, J. G. (1963). A behavioral theory of the firm. NJ: Englewood Cliffs.

Daft, R. (2012). Organization theory and design. Nelson Education.

Daily, C. M., Dalton, D. R., \& Cannella, A. A. (2003). Corporate governance: Decades of dialogue and data. Academy of Management Review, 28(3), 371-382. https://doi.org/10.5465/amr.2003.10196703

Dalton, D. R., Daily, C. M., Johnson, J. L., \& Ellstrand, A. E. (1999). Number of directors and financial performance: A meta-analysis. Academy of Management Journal, 42(6), 674-686.

Davis, G. F. (1991). Agents without principles? The spread of the poison pill through the intercorporate network. Administrative Science Quarterly, 583-613. https://doi.org/10.2307/2393275

Donaldson, L. (1990). The ethereal hand: Organizational economics and management theory. Academy of Management Review, 15(3), 369-381. https://doi.org/10.5465/amr.1990.4308806

Epstein, M. J., \& Roy, M. J. (2004). How does your board rate?. Strategic Finance, 85(8), 24.

Fama, E. F., \& Jensen, M. C. (1983). Separation of ownership and control. The Journal of Law and Economics, 26(2), 301-325. https://doi.org/10.1086/467037

Financial Times. (2018a). Deutsche Bank and VW pay price for shambolic governance: Shortcomings of two-tier board structure evident at teetering German titans. Retrieved April 16, 2018, from https://www.ft.com/content/e19c1114-3f29-11e8-b9f9-de94fa33a81e

Financial Times. (2018b). Carillions demise spurs call for action against Big Four. Retrieved May 16, 2018, from https://www.ft.com/content/5093deb6-5821-11e8-b8b2-d6ceb45fa9d0

Financial Times. (2018c). Carillion's conflicted auditors require less conflicted numbers. Retrieved May 17, 2018, from https://www.ft.com/content/cbee9192-5901-11e8-bdb7-f6677d2e1ce8 
Finkelstein, S. (1992). Power in top management teams: Dimensions, measurement, and validation. Academy of Management Journal, 35(3), 505-538.

Finkelstein, S., \& Mooney, A. C. (2003). Not the usual suspects: How to use board process to make boards better. The Academy of Management Executive, 17(2), 101-113. https://doi.org/10.5465/ame.2003.10025204

Forbes, D. P., \& Milliken, F. J. (1999). Cognition and corporate governance: Understanding boards of directors as strategic decision-making groups. Academy of Management Review, 24(3), 489-505. https://doi.org/10.5465/amr.1999.2202133

Gabrielsson, J., \& Huse, M. (2004). Context, behavior, and evolution: Challenges in research on boards and governance. International Studies of Management \& Organization, 34(2), 11-36.

Gabrielsson, J., Huse, M., \& Minichilli, A. (2007). Understanding the leadership role of the board chairperson through a team production approach. International Journal of Leadership Studies, 3(1), 21-39.

Hambrick, D. C., Werder, A. V., \& Zajac, E. J. (2008). New directions in corporate governance research. Organization Science, 19(3), 381-385. https://doi.org/10.1287/orsc.1080.0361

Hendry, K. P., Kiel, G. C., \& Nicholson, G. (2010). How boards strategise: A strategy as practice view. Long Range Planning, 43(1), 33-56. https://doi.org/10.1016/j.lrp.2009.09.005

Hillman, A. J., \& Dalziel, T. (2003). Boards of directors and firm performance: Integrating agency and resource dependence perspectives. Academy of Management Review, 28(3), 383-396. https://doi.org/10.5465/amr.2003.10196729

Howard, A. (2010). Groupthink and corporate governance reform: Changing the formal and informal decision making processes of corporate boards. S. Cal. Interdisc.

Huse, M. (1998). Researching the dynamics of board-stakeholder relations. Long Range Planning, 31(2), 218-226. https://doi.org/10.1016/S0024-6301(98)00006-5

Huse, M. (2007). Boards, governance and value creation: The human side of corporate governance. Cambridge University Press. https://doi.org/10.1017/CBO9780511611070

Huse, M. (2008). Accountability and creating accountability: A framework for exploring behavioural perspectives of corporate governance. The Value Creating Board, pp. 51-72. Routledge.

Huse, M. (2008). Exploring methods and concepts in studies of board processes. The value creating board: Corporate governance and organizational behavior, pp. 221-233. Routledge.

Huse, M., \& Gabrielsson, J. (2012). Board leadership and value creation: an extended team production approach. The SAGE Handbook of Corporate Governance, 233. https://doi.org/10.4135/9781446200995.n12

Huse, M., Hoskisson, R., Zattoni, A., \& Viganò, R. (2011). New perspectives on board research: Changing the research agenda. Journal of Management \& Governance, 15(1), 5-28. https://doi.org/10.1007/s10997-009-9122-9

Janis, I. L. (2015). Groupthink: The desperate drive for consensus at any cost. Classics of Organization Theory, $161-168$.

Johnson, J. L., Daily, C. M., \& Ellstrand, A. E. (1996). Boards of directors: A review and research agenda. Journal of Management, 22(3), 409-438. https://doi.org/10.1177/014920639602200303

Kaplan, R. S., \& Norton, D. P. (1993). Putting the balanced scorecard to work. Harvard Business Review, 71(5), 134-140.

Mace, M. L. (1971). Directors: Myth and Reality.

Mace, M. L. (1972). The President and the Board of Directors. Harvard Business Review, 50(2), 37-48.

Machold, S., Huse, M., Minichilli, A., \& Nordqvist, M. (2011). Board leadership and strategy involvement in small firms: A team production approach. Corporate Governance: An International Review, 19(4), 368-383. https://doi.org/10.1111/j.1467-8683.2011.00852.x

Minichilli, A., Zattoni, A., Nielsen, S., \& Huse, M. (2012). Board task performance: An exploration of micro-and macro-level determinants of board effectiveness. Journal of Organizational Behavior, 33(2), 193-215. https://doi.org/10.1002/job.743

Nadler, D. A. (2004). Building better boards. Harvard Business Review, 82(5), 102-105. 
Ng, W., \& Cock, C. D. (2002). Battle in the boardroom: A discursive perspective. Journal of Management Studies, 39(1), 23-49. https://doi.org/10.1111/1467-6486.00281

Norreklit, H. (2000). The balance on the balanced scorecard a critical analysis of some of its assumptions. Management Accounting Research, 11(1), 65-88. https://doi.org/10.1006/mare.1999.0121

Nørreklit, H. (2003). The balanced scorecard: what is the score? A rhetorical analysis of the balanced scorecard. Accounting, Organizations and Society, 28(6), 591-619. https://doi.org/10.1016/S0361-3682(02)00097-1

Northcott, D., \& Smith, J. (2011). Managing performance at the top: a balanced scorecard for boards of directors. Journal of Accounting \& Organizational Change, 7(1), 33-56. https://doi.org/10.1108/18325911111125531

Para-González, L., Jiménez-Jiménez, D., \& Martínez-Lorente, A. R. (2018). Exploring the mediating effects between transformational leadership and organizational performance. Employee Relations, 40(2), 412-432. https://doi.org/10.1108/ER-10-2016-0190

Pearce, J. A., \& Zahra, S. A. (1991). The relative power of CEOs and boards of directors: Associations with corporate performance. Strategic Management Journal, 12(2), 135-153. https://doi.org/10.1002/smj.4250120205

Pettigrew, A. M. (1992). On studying managerial elites. Strategic Management Journal, 13(S2), 163-182. https://doi.org/10.1002/smj.4250130911

Pettigrew, A., Thomas, H., \& Whittington, R. (2002). Strategic management: the strengths and limitations of a field. Handbook of Strategy and Management, 3.

Pye, A. (2002). The changing power of 'explanations': Directors, academics and their sensemaking from 1989 to 2000. Journal of Management Studies, 39(7), 907-925. https://doi.org/10.1111/1467-6486.00317

Pye, A., \& Pettigrew, A. (2005). Studying board context, process and dynamics: Some challenges for the future. British Journal of Management, 16(s1), S27-S38. https://doi.org/10.1111/j.1467-8551.2005.00445.x

Roberts, J., McNulty, T., \& Stiles, P. (2005). Beyond agency conceptions of the work of the non-executive director: Creating accountability in the boardroom. British Journal of Management, 16(s1), S5-S26. https://doi.org/10.1111/j.1467-8551.2005.00444.x

Samra-Fredericks, D. (2000). An Analysis of the Behavioural Dynamics of Corporate Governance-a talk-based ethnography of a UK manufacturing 'board-in-action'. Corporate Governance: An International Review, 8(4), 311-326. https://doi.org/10.1111/1467-8683.00210

Schmidt, S. L., \& Brauer, M. (2006). Strategic governance: How to assess board effectiveness in guiding strategy execution. Corporate Governance: An International Review, 14(1), 13-22. https://doi.org/10.1111/j.1467-8683.2006.00480.x

Sonnenfeldt, J. A. (2002). What makes great boards great. Harvard Business Review, 80(9), 106-113.

Voelpel, S. C., Leibold, M., \& Eckhoff, R. A. (2006). The tyranny of the Balanced Scorecard in the innovation economy. Journal of Intellectual Capital, 7(1), 43-60. https://doi.org/10.1108/14691930610639769

Westphal, J. D., \& Bednar, M. K. (2005). Pluralistic ignorance in corporate boards and firms' strategic persistence in response to low firm performance. Administrative Science Quarterly, 50(2), 262-298. https://doi.org/10.2189/asqu.2005.50.2.262

Westphal, J. D., \& Zajac, E. J. (1998). The symbolic management of stockholders: Corporate governance reforms and shareholder reactions. Administrative Science Quarterly, 127-153. https://doi.org/10.2307/2393593

Zahra, S. A., \& Pearce, J. A. (1989). Boards of directors and corporate financial performance: A review and integrative model. Journal of Management, 15(2), 291-334. https://doi.org/10.1177/014920638901500208

Zattoni, A., \& Cuomo, F. (2008). Why adopt codes of good governance? A comparison of institutional and efficiency perspectives. Corporate Governance: An International Review, 16(1), 1-15. https://doi.org/10.1111/j.1467-8683.2008.00661.x

Zhu, H., Wang, P., \& Bart, C. (2016). Board processes, board strategic involvement, and organizational performance in for-profit and non-profit organizations. Journal of Business Ethics, 136(2), 311-328. https://doi.org/10.1007/s10551-014-2512-1 